DOI https://doi.org/10.30525/978-9934-26-110-7-73

\title{
ДІАЛОГ КУЛЬТУР ПІД ЧАС ВИВЧЕННЯ НЕРІДНОЇ МОВИ
}

\author{
Варава C. B. \\ старший викладач кафедри мовної підготовки 2 \\ Харківський національний університет імені В. М. Каразіна \\ м. Харків, Украӥна \\ Івлсва С. М. \\ старший викладач кафедри мовної \\ та загальногуманітарної підготовки іноземиів \\ Одеський національний університет імені I. І. Мечникова \\ м. Одеса, Украӥна
}

Здобування іноземними студентами освіти в Україні $є$ однією 3 важливих характеристик університету світового рівня.

Освіта, як фактор формування особистості, повинна базуватися на принципах, які враховують той факт, що іноземна мова стає в повній мірі засобом міжкультурної комунікації, важливим та дієвим інструментом навчального процесу вцілому та міжособистісних стосунків викладачів зі студентами-іноземцями [3, с. 46].

За допомогою різних методів та видів комунікації стає можливим навчання студентів, що належать до різних культур та світоглядів. Оволодіння мовою країни навчання $є$ важливим й необхідним компонентом навчального процесу студентів-іноземців за будь-якою спеціальністю. В умовах єдиного інформаційного простору людства, наявності високо розвинутих інформаційних технологій, що надають можливості спілкування людям різних національностей, культурних традицій та віросповідань, актуальною стає теорія діалогу культур, міжкультурна комунікація та компетенція, як засіб порозуміння між націями, спосіб здобування якісної освіти.

Звернемо увагу на те, що під час навчання студентів-іноземців нерідній мові відсутні лекції, тобто монолог викладача й пасивне сприйняття слухача. Заняття спрямовано на організацію ефективного діалогу між викладачем та студентом, де щодалі промова викладача повинна стати найменшою. А також у студентів-іноземців повинна бути сформована міжкультурна мовна компетенція, яка буде корисною в подальшому засвоєнні навчального матеріалу та навчанні в Україні. 
Доведено, що під час навчання нерідній мові студентів-іноземців, які як й викладачі стикаються 3 труднощами, які пов'язані з іншим менталітетом, культурними та історичним традиціями. Ці проблеми впливають на сприйняття та засвоєння мовленнєвих та граматичних моделей.

В таких обставинах набуває актуальності метод діалогу культур, що $€$ невід'ємною частиною у навчанні нерідній мові та подальшого здобуття фахових знань відповідного рівня.

У ЗВО діалог культур реалізується через міжкультурний компонент нерідної мови, що створює найкращі умови для здобуття іноземцями освіти в Україні [7, с.4].

Формування міжкультурної компетенції на початковому етапі навчання іноземних студентів починається зі формування складових міжкультурної компетенції - мовної та мовленнєвої компетенції.

Шлях співставлення рідної мови з мовою, що вивчається дозволяє оптимізувати навчальний процес, що дає можливість мінімізувати коментарі викладача, і в той самий час, спрощує психологічні процеси засвоєння нової інформації з боку студента та прискорює навчання $[6$, c. 96$]$.

Знані авторитети-лінгвісти: Л.В. Щерба, С.Д. Поливанов, О.О. Реформатський та ін., які будували систему навчання іноземній мові на базі особливостей рідної мови студентів, починаючи з оволодінням абеткою й надалі наголошували на тому, що звучання нерідної мови людина сприймає «крізь призму» звукової системи рідної мови, вони вважали, що це стосується усіх рівнів, усіх явищ мови, що лунає. Фахівці стверджували, що для гарантованого оволодіння нерідною вимовою необхідно, перш за все свідомо відштовхнутися від рідної вимови, системи рідної мови.

Міжкультурний компонент іноземної мови сприяє формуванню у студентів уявлення про діалог культур як про єдину можливу в сучасних полікультурних спільнотах філософію існування [7, с. 4].

Ідея діалогу культур, як відомо, висунута М. М. Бахтіним: «...Ми ставимо чужій культурі нові питання, яких вона сама собі не ставила, ми шукаємо в ній відповіді на ці наші запитання, нові смислові глибини. Без цих питань не можна творчо зрозуміти нічого іншого і чужого...» [1]. Продовжив цю ідею В. С. Біблер, реалізувавши іiї в освіті, розробивши психолого-педагогічну концепцію, принципи і елементи якої можуть бути задіяні у навчанні нерідної мови студентів-іноземців.

Один 3 компонентів методу діалогу культур, який використовується у навчанні нерідній мові базується на порівнянні рідної мови студентів 3 нерідною мовою, яка вивчається. Викладач формує відбір та послі- 
довність презентації навчального матеріалу та пояснення з урахуванням наявності категорії безеквівалентності, розбіжності фонових знань та асоціативного мислення. В роботі з іноземними студентами важливо враховувати відмінну від нашої етнокультурної картину світу.

Важливо звернути увагу до загальних та більш розповсюджених проблем, що виникають протягом навчального процесу в студентівіноземців із різних країн світу. Більшість проблем іноземців під час набування мовної, мовленнєвої та міжкультурної компетенції виникає завдяки приналежності рідної та нерідної мови до різних морфологічних систем (наприклад: аглютинативні - турецька, флективні - російська, українська), й докорінних відмінностей поведінкових моделей, у зв'язку з розбіжностями культурних, етнічних, релігійних традицій. Такі та інші проблеми вирішуються викладачами за допомогою сталих методів та прийомів викладання нерідної мови. Безсумнівно, що коли студенти під час вивчення фонетико-лексичного мінімуму мають реакцію впізнавання, на приклад, із введенням такої лексики як тюркізми та слів іншомовного походження. Впізнавання таких прикладів вимови окремих звуків та слів викликає у студентів позитивний емоційний заряд радості впізнавання та впевненості у тому, що вони впораються 3 такою складною, як їм здається задачею - оволодіння нерідною мовою.

На прикладі таких лексичних тем як, історія, політичний та суспільний лад України, Свята України, історичні пам'ятки країни та міст перебування підчас навчання, в студентів-іноземців відбувається відпрацювання здобутих знань навичок використання мовних та мовленнєвих моделей.

Виховна та профорієнтаційна робота $\epsilon$ невід'ємною частиною навчального процесу студентів-іноземців. Викладачі ЗВО проводять тематичні бесіди, просвітницькі лекції, екскурсії до цікавих міст. Саме підчас проведення таких заходів в студентів-іноземців відбувається, безпосередньо на практиці міжкультурна комунікація та діалог культур. Студенти «вживу» стикаються з іншою культурою, з іншими законами існування, нормами та правилами, що існують в Україні.

Улюбленим заходами студентів-іноземців є екскурсії, лекції та бесіди про родинні стосунки та традиції (весілля, поховання), що дуже різняться в Україні, Марокко, Китаї, Туреччині, про державні символи України. На відповідних заходах розглядаються історичні, культурні та релігійні традиції рідної країни та України.

Під час виховних заходів та участі у наукових конференціях, до яких залучаються студенти відбувається, безпосередньо на практиці, міжкультурна комунікація та діалог культур. 
Аналізуючи, порівнюючи та співвідносячи культуру, мову, звичаї, традиції своєї країни, своєї рідної культури зі знаннями, що здобуваються під час навчання в інший культурі, іншою мовою, в іншому соціумі здобувач освіти швидше опановує, глибше засвоює нову для себе мову, стимулюється та мотивується до навчання.

Здобуті під час навчання знання про культуру, звичаї, систему правил та норм в українському суспільстві надає студенту бути спроможним до міжкультурного спілкування, взаємодіяти 3 представниками культури країни навчання засобами нерідної мови.

\section{Література:}

1 Бахтин М. Естетика словесного творчества / М. М. Бахтін. М.: МДУНнауково-методичний збірник. Вип. 3. С. 196.

2 Варава С. В. Формирование профессионально ориентированной лингвистической компетенции в русском языке у иностранных студентов инженерных специальностей на начальном этапе с использованием технологий дистанционного обучения. Русский язык и литература в пространстве мировой культуры: материалы ХІІІ Конгресса, МАПРЯЛ В 15 т., Т. 10., 2015. С. 194-199.

3 Вдовіна О. О. Особливості формування комунікативної компетенції іноземних студентів. Херсон: Молодий вчений, 2019. № 5.1 (69.1). С. 47-50.

4 Застровський О. А., Пасик Л. А. Поняття міжкультурної комунікації та порівняльна характеристика німецької та української культур (на матеріалі німецької мови). URL:http://esnuir.eеnu.edu.ua/ handle/123456789/1634, 2010. (дата звернення: 01.03.2020), 10 с.

5 Daphne Koller / TED Global2012/ WHAT WE'RE LEARNING FROM ONLINE EDUCATION. https://www.ted.com/talks/daphne_koller_ what_we_re_learning_from_online_education/transcript\#t-564 (Дата звернення 08.04.2021).

6 Климкина О.И., Зарипова-Четин Ч. Русский алфавит: от А до Я за один урок [для говорящих на турецком языке]. Русский язык за рубежом. 2016. № 6. С. 94-102.

7 Мігрін П. І. Обучение иностранному языку через диалог разных культур. https://naub.oa.edu.ua//2015/навчання-іноземної-мови-як-діалогуpi/\# (Дата звернення 10.07.2020).

8 Напольнова Е.М. Особенности преподавания русского языка в турецкой аудитории. Русский язык за рубежом. 2008. № 4. С. 96-97. 